\title{
GAMBARAN PELAKSANAAN 5 PILAR SANITASI TOTAL BERBASIS MASYARAKAT DI KELURAHAN KASTURIAN KOTA TERNATE
}

\section{Description Of The Implementation Of The 5 Pillars Of Community-Based Total Sanitation In Kasturian Village, Ternate City}

\author{
Vebby Regista*1 ${ }^{1}$, Aida Fitria ${ }^{2}$, Masni A Kadir \\ ${ }^{1}$ Puskesmas Perawatan Siko Kota Ternate \\ ${ }^{2}$ Dinas Kesehatan Kota Ternate \\ ${ }^{3}$ Puskesmas Perawatan Siko Kota Ternate \\ (vebbyswanda@gmail.com, 081242473198)
}

\begin{abstract}
ABSTRAK
Kesehatan lingkungan merupakan hal yang penting dalam meningkatkan kesehatan masyarakat, salah satu masalah kesehatan lingkungan adalah sanitasi yang buruk. Perbaikan sanitasi termasuk dalam target perbaikan di Indonesia untuk mencapai Suntainable Development Goals (SDG's) tahun 2030, saat ini masih menjadi kendala karena kurang kesadaran masyarakat akan sanitasi lingkungan seperti rumah tangga masalah buang air besar sembarangan, pengolahan limbah rumah tangga, pengolahan air bersih dan sampah. Kejadian diare di Wilayah Kerja Puskesmas Perawatan Siko, 11.8\% (24 kasus) dari 202 kasus Diare di Tahun 2020 Terjadi di Kelurahan Kasturian Kota Ternate. Tujuan penelitian untuk mengetahui Gambaran Pelaksanaan 5 Pilar Sanitasi Total Berbasis Masyarakat (STBM) di Kelurahan Kasturian Kota Ternate Tahun 2021. Metode penelitian deskriptif dengan teknik analisis kuantitatif pada 43 Responden di Kelurahan Kasturian Kota Ternate. Data yang diperoleh dengan mengunakan Kuesiner mengunakan Google Form dan dianalisa mengunakan SPSS Software. Hasil analisis diketahui Pilar 1 Stop Buang air besar sembarangan (BABS), diketahui masih ada Sanitasi Belum Layak / Cubluk 20.9\% . Pilar 2 Sanitasi Total Berbasi Masyarakat Cuci Tangan Pakai Sabun (CTPS) diketahui CTPS dengan benar 83.7. Pilar 3 menyimpan peralatan pangan dengan tepat 90,7\%, menyimpan peralatan pengolahan pangan dengan tepat $95,3 \%$, menutup makanan dan minuman dengan tepat :100\%. Pilar 4 Pengelolaan Sampah Rumah Tangga Tidak ada sampah beserakan dilingkungan sekitar rumah $62,8 \%$, dan Pilar 5 hanya $27.9 \%$ dalam pengelolaan air limbah yang terhubung ke Instalasi Pengolahan Air Limbah (IPAL) Komunal
\end{abstract}

Kata Kunci: Stbm, Sanitasi, Kesling, Ternate

\begin{abstract}
Environmental health is important in improving public health, one of the environmental health problems is poor sanitation. Sanitation improvement is included in the improvement target in Indonesia to achieve the 2030 Suntainable Development Goals (SDG's), currently it is still an obstacle due to lack of public awareness of environmental sanitation such as household problems with open defecation, household waste treatment, clean water and garbage treatment. The incidence of diarrhea in the Work Area of the Siko Health Center, 11.8\% (24 cases) of 202 cases of diarrhea in 2020 Occurred in Kasturian Village, Ternate City. The purpose of the study was to determine the description of the implementation of the 5 Pillars of Community-Based Total Sanitation (Stbm) in Kasturian Village, Ternate City in 2021. Descriptive research method with quantitative analysis techniques on 43 respondents in Kasturian Village, Ternate City. Data obtained by using a questionnaire using Google Form and analyzed using SPSS Software. The results of the analysis show that Pillar 1 of Stop Opening Open Defecation (BABS), it is known that there is still Inappropriate Sanitation / Cubluk 20.9\%. Pillar 2 Community-Based Total Sanitation Washing Hands with Soap (CTPS) is known to be true for CTPS 83.7. Pillar 3 stores food equipment correctly 90.7\%, stores food processing equipment correctly 95.3\%, closes food and beverages correctly: 100\%. Pillar 4 Household Waste Management There is no waste scattered around the house $62.8 \%$, and Pillar 5 only $27.9 \%$ in waste water management connected to the Communal Wastewater Treatment Plant (IPAL)
\end{abstract}

Keywords: STBM, Sanitation, Kesling, Ternate 


\section{PENDAHULUAN}

Kesehatan lingkungan merupakan hal yang penting dalam meningkatkan kesehatan masyarakat, salah satu masalah kesehatan lingkungan adalah sanitasi yang buruk (1). Perbaikan sanitasi termasuk dalam target perbaikan di Indonesia untuk mencapai Suntainable Development Goals (SDG's) tahun 2030, saat ini masih menjadi kendala karena kurang kesadaran masyarakat akan sanitasi lingkungan rumah tangga mengenai masalah buang air besar sembarangan, pengolahan limbah rumah tangga, pengolahan air bersih dan sampah (Kemenkes RI, 2014) ${ }^{(2)}$. Progam sanitasi total berbasis masyarakat (STBM) dilakukan untuk mengubah perilaku hygiene dan sanitasi melalui pemberdayaan masyarakat dengan cara pemicuan dalam pelaksanaanya terdapat 5 pilar yaitu stop buang air besar sembarangan, cuci tangan pakai sabun, pengolaan air minum dan makanan rumah tangga, pengamanan sampah rumah tangga, dan pengamanan limbah cair rumah tangga (Kemenkes RI, 2014) ${ }^{(2)}$.

Progam STBM mempunyai indikator outcome dan output. Indikator outcome yaitu menurunkan kejadian penyakit berbasis lingkungan yang berkaitan dengan sanitasi dan perilaku. Sedangkan indikator output yaitu setiap individu dan komunitas akses terhadap sarana sanitasi dasar untuk mewujudkan ODF (Open Defecation Free), setiap rumah tangga dapat menerapkan pengelolahan air minum dan makanan yang aman, setiap rumah tangga dan sarana pelayanan umum tersedia fasilitas cuci tangan sehingga semua orang dapat mencuci tangan dengan benar, setiap rumah tangga mengelolah limbah dan sampah dengan benar.

(3) Kejadian diare di Wilayah Kerja Puskesmas Perawatan Siko, 11.8\% (24 kasus) dari 202 kasus Diare di Tahun 2020 Terjadi di Kelurahan Kasturian Kota Ternate

Sanitasi yang buruk dapat menyebabkan penyakit, salah satu penyakit yang disebabkan oleh sanitasi lingkungan adalah diare, penyakit diare merupakan penyakit endemis dengan kejadian luar Pelaksanaan Program 5 Pilar Sanitasi Total Berbasis Mayarakat diharapkan dapat terlaksana dengan baik sehingga dapat mengatasi masalah- masalah kesehatan yang disebabkan oleh buruknya pelaksanaan sanitasi di rumah tangga. ${ }^{(4)}$

\section{METODE PENELITIAN}

Penelitian ini penelitian deskriptif kuantitatif, dilaksanakan di Kelurahan Kasturian Kota Ternate Tahun 2021, Populasi 144 dan 43 sampel, Pengambilan sampel dilakukan dengan pengambilan sampel acak berdasarkan area atau wilayah (Cluster Random Sampling), teknik pengumpulan data pada penelitian ini adalah dengan mengunakan kuisioner dengan Google Form dan analisis dengan mengunakan SPSS Software, Penyajian data dengan mengunakan table distribusi frekuensi pelaksanaan pada tiap Pilar Sanitasi Total Berbasis Masyarat (STBM) untuk melihat gambaran pelaksanaan Sanitasi Total Berbasis Masyarakat di Kelurahan Kasturian. 
HASIL

Tabel 1. Kepemilikan Jamban

\begin{tabular}{lcc}
\hline \multirow{2}{*}{ Pilar 1 } & \multicolumn{2}{c}{ Kepemilikan Jamban } \\
\cline { 2 - 3 } & Total & Persen $(\boldsymbol{\%})$ \\
\hline Tidak & 4 & 9.3 \\
Ya & 39 & 90.7 \\
Total & 43 & 100.0 \\
\hline
\end{tabular}

Sebagian Besar Responden 39 (90.7\%) memiliki Jamban Sendiri Dirumah dan masih ada $4(9.3 \%)$ Responden yang tidak memiliki jamban sendiri dirumah yaitu dengan menumpang dan buang air ke pantai / sungai

Tabel 1.1 Jamban Leher Angsa

\begin{tabular}{lcc}
\hline \multirow{2}{*}{ Pilar 1 } & \multicolumn{2}{c}{ Jamban Leher Angsa } \\
\cline { 2 - 3 } & Total & Persen $(\%)$ \\
\hline Tidak & 0 & 0 \\
Ya & 43 & 100.0 \\
Total & 43 & 100.0 \\
\hline
\end{tabular}

Diketahui Bahwa Total Semua Responden 43 (100\%) Sudah Buang Air di Jamban Jenis Leher Angsa, namun tengki septik yang digunakan masih banyak yang dialirkan ke sungai / pantai.

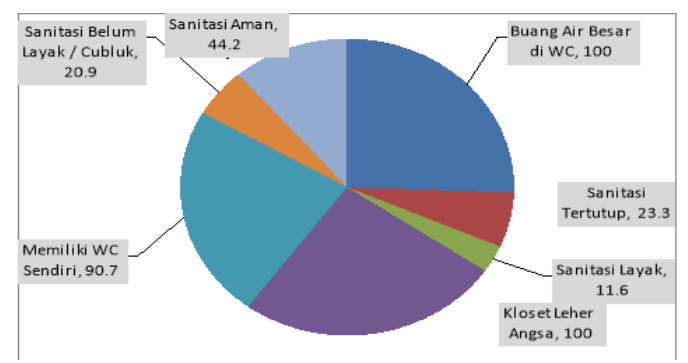

\section{Gambar1. Diagram Pelaksanaan Pilar 1 Stop Babs}

Sebagian Besar 19 (44.2\%) Responden Tempat Pembuangan Kotoran Tinja Rumah Tangga nya adalah Dibuang / disalurkan ke tangki septik kedap / tidak bocor dan dilakukan penyedotan secara berkala (2-5 tahun sekali).
Atau disalurkan ke Sistem Pengolahan Air Limbah (SPAL), 10 (23.3\%) Responden dibuang / disalurkan ke tampungan tidak kedap / cubluk / lubang tanah yang masih bisa meresap ke dalam tanah, 9 (20.9\%) Responden masih dibuang / disalurkan ke drainase / kolam / sawah / sungai / barangka / laut / pantai / kebun / lingkungan sekitar dan hanya sekitar 5 (11.6\%) Responden yang dibuang / disalurkan ke tangki septik kedap / tidak bocor. Tidak / belum pernah disedot dalam kurun waktu 5 tahun terakhir. Atau termasuk bangunan baru kurang dari 5 tahun.

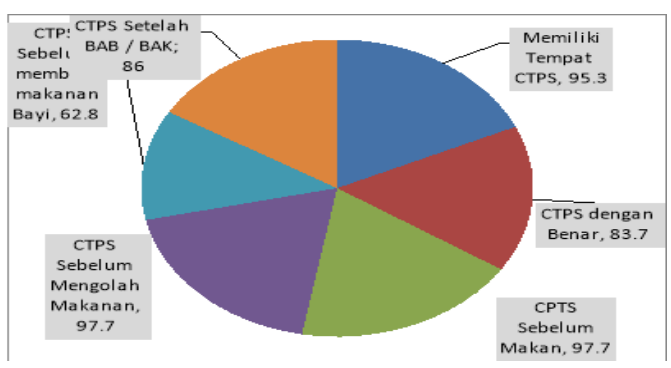

Gambar 2. Diagram Pelaksanaan Pilar 2 CTPS

Diketahui Sebagian Besar 41 (95.3\%) Responden telah memiliki Sarana Tempat Cuci Tangan Pakai Sabun, sebagian Besar 36 (83.7\%) Responden mampu melakukan 6 langkah CTPS dengan benar, 42 (97.7\%) Responden Melakukan CTPS Sebelum Makan, Sebagian Besar 42 (97.7\%) Responden Melakukan CTPS Sebelum mengolah dan menghidangkan makanan, 27 (62.8\%) Responden Melakukan CTPS Sebelum mengolah / menghidangkan makanan dan 37 (86.0\%) Responden Melakukan CTPS Setelah buang air besar / kecil 


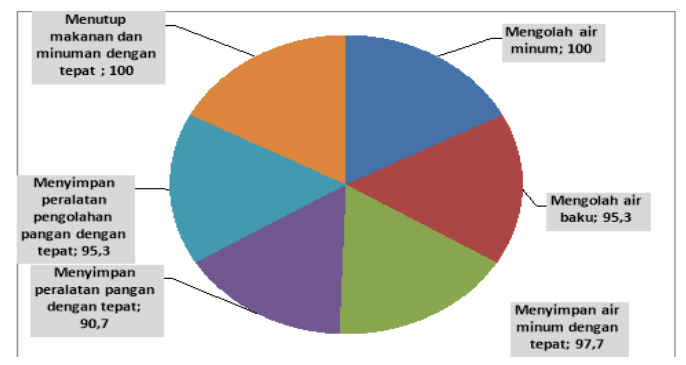

Gambar 3. Diagram Pelaksanaan Pilar 3 (Pengolahan dan Penyimpanan Makanan dan Minuman Rumah Tangga)

Seluruh Responden $43 \quad$ (100\%) mengkonsumsi air minum yang melalui proses pengolahan (misal : merebus sampai mendidih, klorinasi, UV, sodis, filtrasi, keramik filter, RO), sebagian besar Responden 41 (95.3\%) melakukan pengolahan jika air baku keruh (seperti) pengendaan atau penyaringan, sebagian besar Responden 42 (97.7\%) menyimpan air minum di dalam wadah yang tertutup rapat, kuat, terbuat dari bahan stainless steel, keramik, kaca dan jika terbuat dari plastik tanda gelas dan garpu dan diambil dengan cara yang aman (tidak tersentuh tangan atau mulut), sebagian Besar Responden 39 (90.7\%) menyimpan peralatan pangan dengan aman dan menjaga kebersihannya, termasuk seluruh peralatan makan (piring, sendok, garpu, dll) tidak kotor, tidak berdebu dan disimpan di tempat yag terlindung dari tikus, kecoa, dll, sebagian besar responden 41 (95.3\%) menyimpan peralatan pengolahan pangan dengan aman dan menjaga kebersihannya, termasuk seluruh peralatan masak (panci, penggorengan, dll ) tidak kotor, tidak berdebu, disimpan di tempat yang bersih diketahui seluruh Responden 43 (100.0\%) menutup makanan dan minuman yang dengan baik dan benar disajikan.

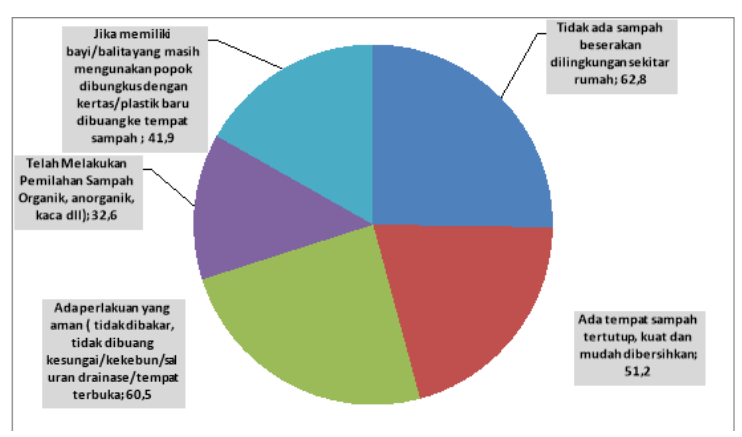

Gambar 4. Diagram Pelaksanaan Pilar 4 (Pengolahan dan Penyimpanan Makanan dan Minuman Rumah Tangga)

Diketahui lebih dari separuh responden 27 (62.8\%) Tidak ada sampah berserakan di lingkungan sekitar rumahnya, 22 (51.2\%) responden memiliki tempat sampah yang tertutup, kuat dan mudah dibersihkan, diketahui lebih dari separuh responden 26 (60.5\%) melakukan perlakuan yang aman (tidak dibakar, tidak dibuang ke sungai/kebun/saluran drainase/ tempat terbuka) terhadap sampah, kebanyakan responden 29 (67.4\%) belum melakukan pemilahan sampah (organik, anorganik, kaca, dll) dan 18 (4.9\%) responden telah melakukan perlakuan yang aman terhadap bekas popok bayi dengan dibungkus dengan kerumah tanggaas / plastik sebelum dibuang ke tempat sampah. dan sisa responden tidak memiliki bayi / balita di rumahnya. 


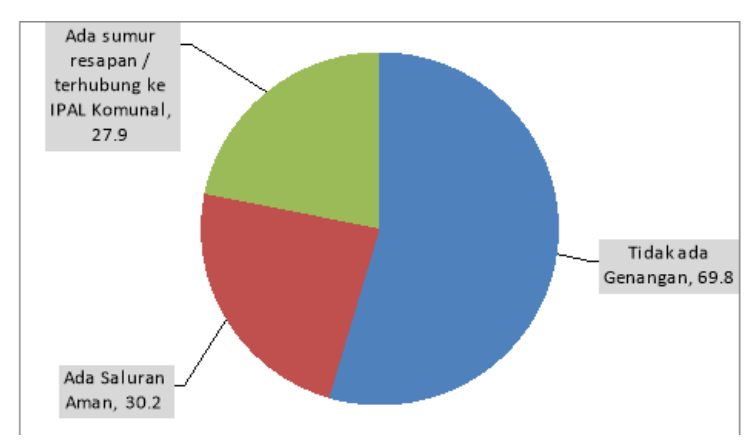

Gambar 4. Diagram Pelaksanaan Pilar 4 (Pengolahan dan Penyimpanan Makanan dan Minuman Rumah Tangga)

Lebih dari Separuh Responden 30 (69.8\%) Tidak terlihat genangan air di sekitar rumah karena limbah cair domestik (Limbah cair dari rumah tangga yang tergenang dapat menjadi sumber dari vektor penyakit, termasuk kran umum atau WC umum), diketahui sebagian besar responden 30 (69.8\%) tidak memiliki saluran pembuangan limbah cair rumah tangga (non kakus) yang kedap dan tertutup, diketahui sebagian besar responden $31 \quad(72.1 \%)$ responden tidak memiliki saluran pembuangan limbah cair yang terhubung dengan sumur resapan dan atau sistem pengolahan limbah (IPAL Komunal/ sewerage system)

\section{KESIMPULAN DAN SARAN}

Hasil Gambaran Pelaksanaan 5 Pilar Sanitasi Total Berbasis Masyarakat di Kelurahan Kasturian di Kota Ternate Tahun 2021 diketahui bahwa :

1. Pilar 1 Sanitasi Total Berbasi Masyarakat STOP BABS dari 43 Responden diketahui
Sanitasi Aman, 44.2\%, Sanitasi Layak, $11.6 \%$, Sanitasi tertutup, $23.3 \%$ dan Sanitasi Belum Layak / Cubluk ada 20.9\%

2. Pilar 2 Sanitasi Total Berbasi Masyarakat CTPS dari 43 Responden diketahui sabagian besar memiliki tempat CTPS, 95.3\%, CTPS dengan benar, $83.7 \%$, CPTS sebelum makan, 97.7\%, CTPS Sebelum mengolah makanan, 97.7\%, CTPS sebelum memberi makanan bayi, $62.8 \%$ dan CTPS Setelah BAB / BAK 86\%

3. Pilar 3 Sanitasi Total Berbasi Masyarakat pengelolaan air minum dan makanan sehat dari 43 Responden diketahui mengolah air minum:100\%, mengolah air baku 95,3\%, menyimpan air minum dengan tepat: $97,7 \%$, menyimpan peralatan pangan dengan tepat $90,7 \%$, menyimpan peralatan pengolahan pangan dengan tepat:95,3\% menutup makanan dan minuman dengan tepat $: 100 \%$

4. Pilar 4 Sanitasi Total Berbasi Masyarakat pengelolaan sampah rumah tangga dari 43 Responden diketahui tidak ada sampah beserakan dilingkungan sekitar rumah $62,8 \%$, ada tempat sampah terumah tanggautup, kuat dan mudah dibersihkan $51,2 \%$, ada perlakuan yang aman ( tidak dibakar, tidak dibuang kesungai/kekebun/saluran drainase/tempat terbuka $60,5 \%$, telah melakukan pemilahan sampah organik, anorganik, kaca dll) $32,6 \%$ dan jika memiliki 
bayi/balita yang masih mengunakan popok dibungkus dengan kerumah Tanggaas/plastik baru dibuang ke tempat sampah 41,9

5. Pilar 5 Sanitasi Total Berbasi Masyarakat Pengelolaan Limbah Cair Rumah Tangga dari 43 Responden diketahui Tidak ada Genangan :69.8\%, Ada Saluran Aman $30.2 \%$ dan Ada sumur resapan / terhubung ke IPAL Komunal $27.9 \%$.

Diharapkan dapat menjadi masukan dalam merencanakan program kesehatan di pukesmas sebagai upaya perbaikan dalam pelaksanaan program Sanitasi Total Berbasis Masyarakat, contohnya yaitu dengan mengadakan penyuluhan atau pendidikan kesehatan yang berkaitan dengan sanitasi total berbasis masyarakat dan juga memperkuat pemicuan dan partisipasi masyarakat dalam mengetahui pentingnya pelaksanaan Sanitasi Total Berbasis masyarakat dalam upaya merubah perilaku masyarakat untuk hidup sehat secara mandiri.

\section{DAFTAR PUSTAKA}

1. Profil STBM, 2017, Data dan Informasi sanitasi total berbasis masyarakat di Indonesia, http://stbm-indonesia.org/ diakses pada tanggal 04/03/2017

2. Kementerian Kesehatan RI, 2014, Kurikulum dan Modul Pelatihan Fasilitator Sanitasi Total Berbasis Masyarakat (STBM) di Indonesia, Jakarta

3. Elsa Putri Lahudin, Sanitasi Total Berbasis Masyarakat (Stbm) Dengan Kejadian Diare. Jombang; 2017

4. Direktorat Penyehatan Lingkungan Ditjen PP- PL. 2011, Pedoman Pelaksanaan

Sanitasi Total Berbasis Masyarakat, Jakarta

5. Bintari, Defina Putri Arief, Hubungan Tingkat Pengetahuan Sanitasi Total Berbasis Masyarakat (Stbm) Pilar Satu Dengan Perilaku Pemanfaatan Jamban Di Desa Putukrejo Wilayah Kerja Puskesmas Kalipare; 2021

6 Naway, Muhammad Adham Evaluasi Pelaksanaan Sanitasi Total Berbasis Masyarakat STBM Di Kelurahan Moodu Kota Gorontalo; 2015 